\title{
Mitochondrial DNA analysis on remains of a putative son of Louis XVI, King of France and Marie-Antoinette
} \author{
Jean-Jacques Cassiman ${ }^{1}$ \\ ${ }^{1}$ Center for $\mathrm{H}$ uman $\mathrm{G}$ enetics, U niversity of $\mathrm{L}$ euven, B elgium \\ ${ }^{2} \mathrm{~L}$ aboratoire de $\mathrm{G}$ énétique M oléculaire, CH RU, Nantes, France \\ ${ }^{3} \mathrm{P}$ etrus $\mathrm{C}$ ampussingel, Groningen, The $\mathrm{N}$ etherlands \\ ${ }^{4}$ Faculté $L$ ibre des Sciences de la Communication, L evallois-Perret, France
}

E Is Jehaes ${ }^{1}$, R onny Decorte ${ }^{1}$ A lain Peneau ${ }^{2}$, Johan H Petrie ${ }^{3}$, Philippe A B oiry ${ }^{4}$, A nja Gilissen ${ }^{1}$, J ean Paul M oisan ${ }^{2}, \mathrm{H}_{\text {erman Van den Berghe }}{ }^{1}$, Olivier Pascal ${ }^{2}$ and

\begin{abstract}
Carl Wilhelm Naundorff was buried in 1845 in Delft as Louis Charles, Duc de Normandie, 'Louis XVII'. However, the son of Louis XVI and Marie-Antoinette Louis XVII - officially died in the Temple of Paris in 1795. In order to resolve the identity of Naundorff, mitochondrial DNA (mtDNA) D-loop sequences of his remains were compared with the sequences obtained from the hairs of two sisters of Marie-Antoinette, Marie-Antoinette herself, and with the sequences obtained from DNA samples of two living maternal relatives. The mtDNA sequence of a bone sample from Naundorff showed two nucleotide differences from the sequences of the three sisters and four differences from the sequences of living maternal relatives. Based on this evidence it becomes very unlikely that Naundorff is the son of Marie-Antoinette.
\end{abstract}

Keywords: Louis XVII; mitochondrial DNA; ancient DNA; genetic identification

\section{Introduction}

In June 1791, the French royal family (Louis XV I (1754-1793), Marie-A ntoinette (1755-1793), and their children Marie-Thérèse-Charlotte (1778-1851) and Louis-Charles (1785-1795?) (Figure 1) tried to escape from the increasingly hostile Parisian environment. They were arrested in Varennes and were imprisoned in

Correspondence: Prof. D r J ean-Jacques Cassiman, Center for $\mathrm{H}$ uman $\mathrm{G}$ enetics, Campus $\mathrm{G}$ asthuisberg $\mathrm{O} \& \mathrm{~N} 6$, H erestraat 49, B-3000 Leuven, Beglium. Tel: 3216345860; Fax: 3216345997; E-mail: J ean-J acques.C assiman@med. kuleuven.ac.be

R eceived 9 A pril 1998; revised 26 M ay 1998; accepted 27 M ay 1998 the Temple, in Paris. In 1793, the K ing and Q ueen were beheaded but their son and daughter remained imprisoned in the Temple. A ccording to the official records L ouis-Charles died of tuberculosis in the Temple on 8 J une 1795 . Since then, the official version of his death has been repeatedly questioned. One of the most persistent theories claims that it was a substitute who died, while L ouis-Charles escaped out of France. A t the beginning of the 19th century several individuals claimed to be the son of L ouis XVI. O ne of these, Carl Wilhelm $N$ aundorff, could apparently provide sufficient circumstantial evidence to convince ex-members of the court of Versailles of his descent. $N$ aundorff was exiled by the French authorities. He lived for several years in 
London and died in 1845 in Delft (the Netherlands) where he was buried under the name Louis Charles, D uc de Normandie, 'L ouis XVII'. In 1863, the Dutch authorities permitted his descendants to use the name 'de Bourbon', the name of the French royal family. Since then, there has been much speculation about the real identity of Naundorff. In many publications about 'the mystery of Delft', he is considered a swindler and a charlatan. Naundorff was always his own witness, but formal proof of his identity was lacking. He apparently bought his identity from a German whose antecedents could not be traced. This led finally to the opening of Naundorff's coffin in 1950 in Delft for a study of the skeletal remains. A lock of hair from the bottom of his coffin, and the right humerus were removed. The humerus was used to investigate whether Naundorff's death was due to poisoning with arsenic. Since 1950, it has been kept in the archives of the Dutch Forensic Laboratory in Rijswijk. The hair samples from Naundorff were stored in two sealed envelopes in the D elft town archives. These remains were officially made available to us in 1993 for D NA analysis and were used in an attempt to determine the identity of Naundorff.

Identification of human remains by DNA analysis has proved to be a powerful tool in forensic and historical investigations. ${ }^{1}$ A nalysis of DNA extracted from bone has indeed been used successfully in the identification of the Romanov family ${ }^{2}$ and of Josef M engele. ${ }^{3}$ Whilst nuclear polymorphisms provide the necessary information to establish paternal and maternal relationships, mtDNA analysis enables one to determine whether individuals are maternally related. M ost polymorphisms of the mtDNA are concentrated in two hypervariable segments (HVR 1 and HVR 2) in the $D$-loop region, ${ }^{4}$ which is therefore best suited for identification studies. A comparison between the mtDNA of a deceased and a single maternal relative is sufficient to exclude a maternal relationship. ${ }^{5} \mathrm{M}$ oreover, mtDNA is present at high copy numbers in the cells ${ }^{6}$ and is therefore more likely to survive the process of autolysis after death than nuclear D NA . ${ }^{7}$ R ecently, it has been shown that mtD NA analysis can be performed successfully on human remains up to 12000 years old ${ }^{8}$ and even on the skeleton of a Neanderthaler. ${ }^{9}$

$\mathrm{H}$ ere, we present the results of a DNA analysis on the remains of $\mathrm{N}$ aundorff and of maternal relatives of L ouis XVII to establish the identity of Naundorff. In order to obtain unquestionable results, some analyses were also performed independently by another laboratory in Nantes (France).

\section{Materials and Methods}

\author{
Origin, Authenticity and Documentation of the \\ Biological Samples
}

DNA analysis of Naundorff was performed on hair samples and the right humerus, both removed from the coffin during the restoration of his burial place in 1950 in D elft. The hair samples were received under sealed envelopes from the hands of the archivist of the city of Delft in the presence of the mayor of the city. The samples of the humerus (Figure 2a), documented by a scientific report and kept in the original reservoir in the archives of the Forensic Science $L$ aboratories in Rijswijk, were transferred to RD by A D K loosterman and guaranteed to be the original by $\mathrm{F} U$ ddenberg (conservator of the Institute). The maternal mtD NA sequence of the family of Louis XVII (Figure 1 ) was established by hair samples from two sisters of $M$ arie-A ntoinette (M A). M arie-A ntoinette's eldest sister M aria-A nna (1738-1789) spent the last years of her life in the Elisabethinen convent in K lagenfurt (A ustria). A fter her death, she was buried in the crypt of the convent. The monastic order received her legacy which included a rosary belonging to her mother, M aria-Theresia (M T) (1717-1780). This rosary consisted of several medallions containing hair from different children of $\mathrm{M}$ aria-Theresia (Figure 2b). In March 1995, two of the medallions were opened in the presence of numerous witnesses, including a public notary, so that samples of a few hairs from JohannaGabriela (JG) (1750-1762) and Maria-Josepha (MJ) (1751-1767) could be taken. These hairs were authenticated by $\mathrm{Dr} C$ Topper, archivist of the convent of K lagenfurt. In addition, biological material of other maternal descendants, including living descendants, of Louis XVII was analysed. L ouise-M arie (LM ) (1812-1850), Q ueen of B elgium, was the granddaughter of Caroline (CA ) (1752-1814), another daughter of $\mathrm{M}$ aria-Theresia. Several envelopes containing hair from members of the B elgian R oyal Family are kept in the archives of the R oyal Palace in B russels. One envelope with hair from Q ueen Louise-Marie, taken after her death in 1850, was available together with three envelopes containing hair from her daughter Charlotte (CH) (1840-1927), Empress of Mexico, taken at several ages. Comparative samples from living maternal relatives of $M$ arie-A ntoinette were received from Q ueen A nna of R omania (A) (blood sample, taken and authenticated by the physician) and from her brother A ndré de Bourbon Parme (A B) (hair sample, authenticated by PA $B$ oiry). $\mathrm{H}$ air from $\mathrm{M}$ arie-A ntoinette herself was also included in the study and was obtained from two sources. First, from medallions kept in a private collection belonging to $M$ arquise $J$ ane de Bernardières ( $C$ annes). The origin of this hair could only be established from oral information passed from generation to generation in the families who possessed the two medallions. Second, hair from $M$ arie-A ntoinette was taken from a document containing a lock of hair fixed with a silk thread. The document is blind embossed in several places with the three French lilies of de Bourbon and bears the handwriting of $\mathrm{Henri}$, Prince de Bourbon, declaring that, if the seal and thread are intact, the hair is authentic. This object was in the legacy of D r J Stuyt to the library of the U niversity of Nijmegen (the Netherlands). The library transferred the document to the Museum 'Commandery of Saint Jan' in Nijmegen.

A ll transfers of biological samples were documented in writing and authorisation for their use in these investigations 
was obtained from the persons who had legal title to the samples.

\section{Measures for the Prevention of Contamination}

From the outset of this study extreme effort was made to recover ancient DNA samples free of contamination by contemporary DNA. To minimise the risk of surface contamination arising from handling the bone, the surface layer was removed. For D NA extraction only the internal segments of the bone were used. Possible external contaminants of hair samples were removed by a lysis buffer, which proved to be highly efficient in removing contaminating saliva or blood from hair, ${ }^{10}$ followed by a wash procedure in ethanol and $0.9 \% \mathrm{NaCl}$. All extractions were set up in a dedicated laboratory with dedicated equipment. All the extraction reagents (except the phenol and the butanol solution, Triton $\mathrm{X}-100$ and proteinase $\mathrm{K}$ ) were filtered through a Microcon 100 (A micon, Beverly, M A) to remove any contaminating D NA . A mplification was carried out in a different laboratory, so that amplified products never entered the extraction laboratory. Final PCR mixes (except target DNA, Taq polymerase and BSA ) were filtered through a Microcon 100

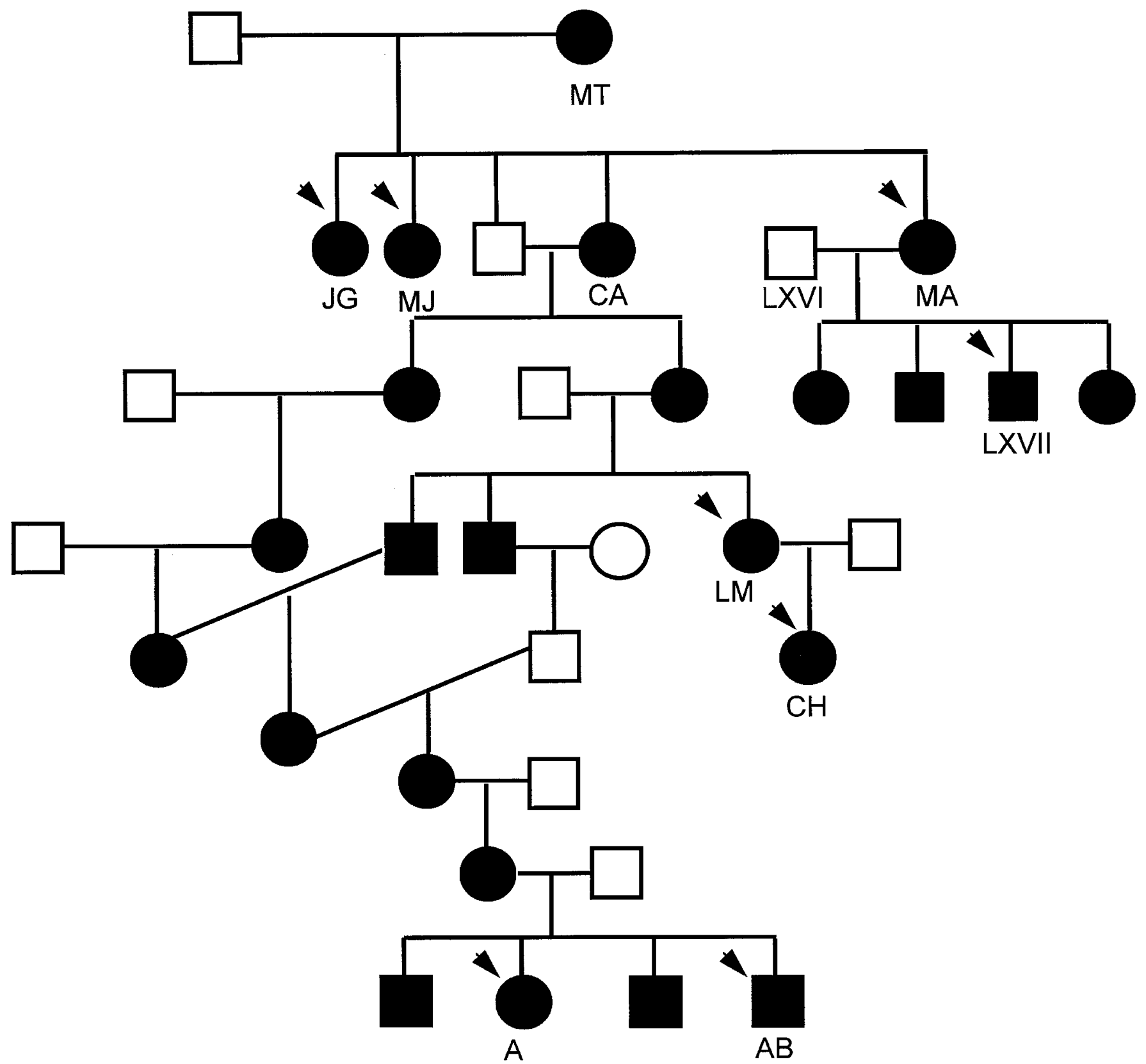

Figure 1 Pedigree of L ouis X VI and M arie-A ntoinette. The maternal lineage of M arie-A ntoinette (H absburg) is marked in black. The son of the royal pair, L ouis-Charles and the maternal relatives analysed in the present study are indicated by arrows. 

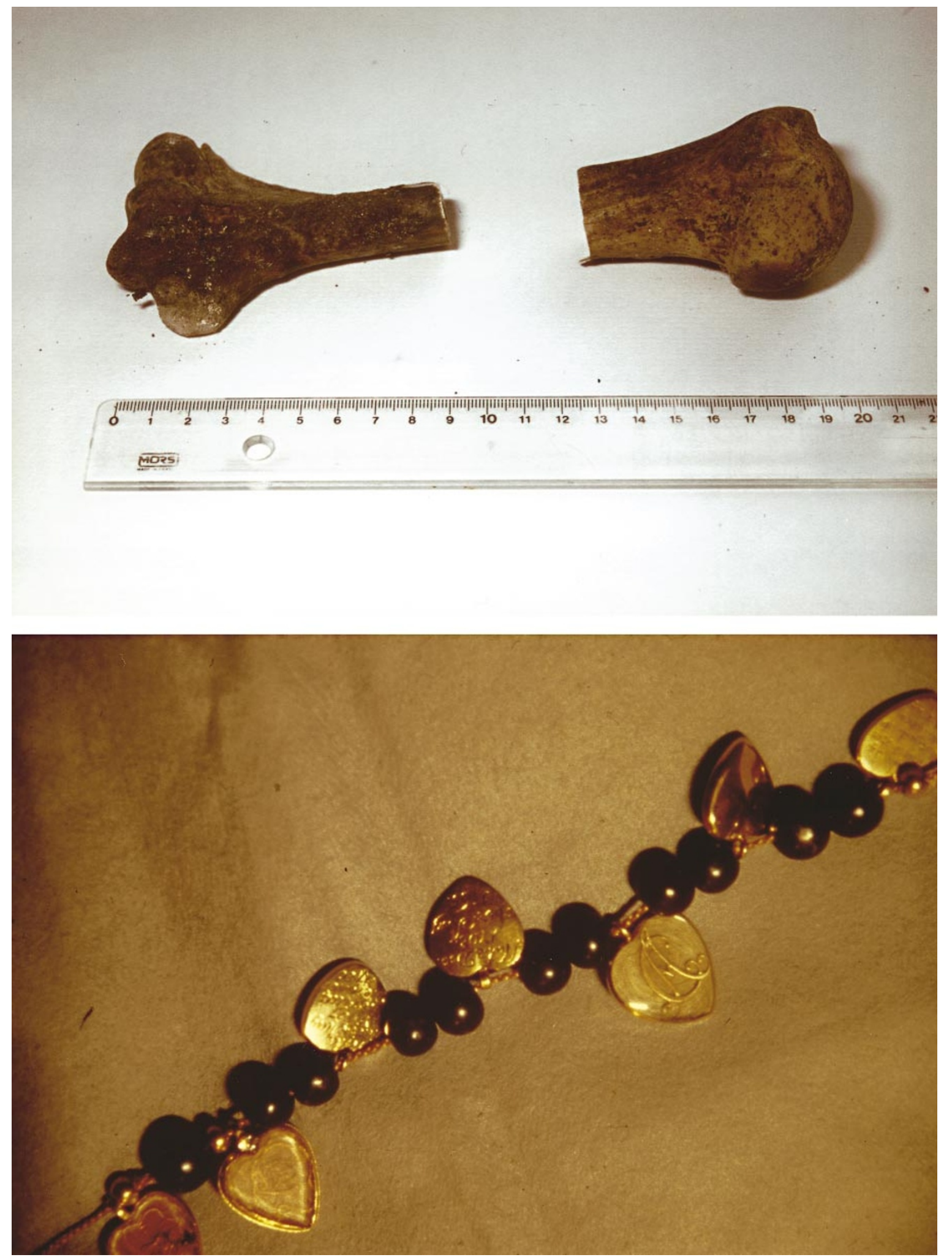

Figure 2 (a) The right humerus of Carl Wilhelm N aundorff removed from the coffin during the restoration of his burial place in 1950. The middle piece of the bone was used in 1950 for investigation of possible arsenic poisoning. $\mathbf{2 b}$ Rosary with the medallions containing hair of J ohanna-G abriela and M aria-J osepha, two aunts of L ouis XVII. 
in order to avoid contamination. A nalysis of PCR products was done in a separate room with dedicated equipment. Gloves were changed regularly to avoid cross-sample contamination. Pipette tips with cotton plugs were used exclusively to prevent carry-over contamination during DNA extraction and pre-PCR. Negative extraction controls and negative PCR controls were taken throughout the entire procedure in order to detect contamination of the used reagents. When the negative controls were positive after PCR, the experiment was rejected. A Iso the sequence of the chief experimenter (EJ) was determined and compared with the sequences obtained on the ancient DNA and identical sequences were rejected.

\section{DNA Extraction}

DNA was extracted from hair shafts according to the procedure described by $\mathrm{H}$ iguchi et al. ${ }^{11}$ except for the concentration of the DNA extract, which was done by filtration on a M icrocon 100 device. A xylene treatment prior to lysis was included in order to remove the presence of 'glue' on the hair which had been taken from medallions. In addition the DTT concentration was increased from $0.039 \mathrm{M}$ to $0.13 \mathrm{~m}$ to dissolve the hair shaft completely.

For DNA extraction of bone, four internal segments of approximately $1 \mathrm{~cm}$ were excised from the humerus. The pieces of bone were ground to powder under liquid nitrogen in a freezer mill (Bel-A rt-Products, Pequannock, MJ). D NA extraction was based on the DNA binding capacity of silica as described by $\mathrm{H}$ öss \& Pääbo ${ }^{12}$ except for incubation in lysis buffer, which was done overnight.

\section{Analysis of the mtDNA D-loop}

A mplification of two overlapping fragments (between 242 and $292 \mathrm{bp}$ ) for each of the two hypervariable regions (430 bp) of the non-coding D-loop was done by a semi-nested PCR method as described by Decorte et al. ${ }^{13}$ and Jehaes et al. ${ }^{14}$ The PCR products were directly sequenced according to a solid phase protocol with the Sanger dideoxy chain termination method ${ }^{15}$ on the automated A LF DNA sequencer (Pharmacia Biotech, Uppsala, Sweden). Most of the sequences were confirmed by a single hot start PCR of 45 cycles using $\mathrm{H}$ otStart Storage and $\mathrm{R}$ eaction Tubes (M olecular Bio-Products, San Diego, CA), as described by the manufacturer, or using A mpliTaq $\mathrm{Gold}^{\mathrm{TM}}$ polymerase (Perkin E Imer, E meryvile, CA ). Some ancient DNA extracts did not contain enough DNA to do a single hot start PCR and could only be amplified by two rounds of PCR .

\section{Y-chromosomal DNA Analysis}

Sex determination was performed by amplification of the $X-Y$ homologous amelogenin gene with a single primer pair, generating a $106 \mathrm{bp}$ and a $112 \mathrm{bp}$ PCR product respectively from the $X$ and $Y$ chromosome. The PCR conditions and the primer pair used, have been described by Sullivan et al. ${ }^{16}$ The fluorescence tagged $P C R$ products were analysed on the $A L F$ DNA sequencer. ${ }^{17}$

Detection of an Haell Restriction Site Polymorphism A common polymorphism (T-to-C transition) at position 16519 between HVR 1 and HVR 2, which creates an HaellI site was analysed. A fragment of $141 \mathrm{bp}$ between position 16407 and 16547 was amplified in a single PCR round of 45 cycles using A mpliTaq $\mathrm{Gold}^{\mathrm{T} M}$ polymerase at an annealing temperature of $55^{\circ} \mathrm{C}$. The $\mathrm{PCR}$ products were digested with $\mathrm{H}$ aellI (5 units) overnight at $37^{\circ} \mathrm{C}$ and analysed on a $4 \%$ agarose gel. Results were confirmed by sequencing the obtained PCR products using the Thermo Sequenase fluorescent labelled primer cycle sequencing kit with 7-deaza-dG TP (A mersham Life Science, Buckinghamshire, England). PCR products were 30 times diluted and five $\mu$ l was added to one pmol of sequencing primer and two $\mu$ of the particular $A, C$, $\mathrm{G}$ or $\mathrm{T}$ mix, provided in the kit. The samples were subjected to $20 \mathrm{cycles}$ of $30 \mathrm{sec}$ at $94^{\circ} \mathrm{C}$ and $30 \mathrm{sec}$ at $60^{\circ} \mathrm{C}$. Six $\mu$ of a formamide buffer was added and the samples were analysed on the A LF DNA sequencer.

\section{Statistical Evaluation}

The significance of the mtDNA match between the two daughters of $E$ mpress $M$ aria-Theresia and the hair sample of $M$ arie-A ntoinette was evaluated by a B ayesian approach. ${ }^{2}$ We consider, $R$, that the mtDNA sequence is from MarieA ntoinette and $R^{\prime}$ that the mtDNA sequence is from an unknown person. The likelihood ratio ( $L R$ ) is defined as follows: $L R=P(E \mid R) / P\left(E \mid R^{\prime}\right)$, where the numerator $P(E \mid R)$ is the probability that the hair sample belonged to $M$ arieA ntoinette (no mutation) and the denominator $P\left(E \mid R^{\prime}\right)$ is the probability that the hair sample belonged to a random individual. The numerator can be evaluated in a manner analogous to $\mathrm{G}$ ill et al. ${ }^{2}-\mathrm{e}^{-\mathrm{gm}}$, where $\mathrm{g}=2$ generational events between the two sisters and $M$ arie-A ntoinette, and $m=1 / 33$, the estimated mutation rate of the mtDNA sequence of the $\mathrm{D}$-loop region according to Parsons et al. ${ }^{18}$ The denominator $\left[P\left(E \mid R^{\prime}\right)\right]$ is simply the number of times an identical sequence is obtained in a pairwise database comparison of 100 B ritish Caucasians $^{19}$ and 119 Belgian individuals (unpublished results) which resulted in 52 identical sequences in 11900 comparisons.

\section{Results}

\section{MtDNA Analysis of Remains of Naundorff}

DNA from Naundorff was obtained from hair samples and from the right humerus (Figure 2a), both removed from the coffin during the restoration of his burial place in 1950 in Delft. Table 1 summarises the number of DNA extractions performed in Leuven and their results. The 62 different extracts of the hair samples from $\mathrm{N}$ aundorff did not yield a reproducible sequence. In total 17 different sequences were found for the 32 different DNA extracts that could be analysed. Two pieces of the caput humerus and two fragments of the condylus were then examined (Figure 2a), representing a total of 13 different extractions. Five different batches of extraction buffer were used. From these 13 extractions, 11 complete sequences were obtained of which nine were identical and two were contaminated. In these two contaminated extracts two overlapping sequences were visualised. O ne of these was identical to the sequence found in the other nine extracts. The common bone sequence showed three polymorphisms 
Table 1 Summary of the DNA extractions and the sequencing results

\begin{tabular}{|c|c|c|c|c|c|c|}
\hline Sample & $\begin{array}{l}\text { Tissue } \\
\text { sample }\end{array}$ & $\begin{array}{l}\mathrm{N} \text { umber of } \\
\text { extractions }\end{array}$ & $\begin{array}{l}\text { Number of } \\
\text { results }\end{array}$ & $\begin{array}{l}\text { Extraction } \\
\text { control } \\
\text { positive }\end{array}$ & $\begin{array}{l}\text { D-loop } \\
\text { Complete } \\
\text { sequence }\end{array}$ & $\begin{array}{l}\text { Incomplete } \\
\text { sequence }\end{array}$ \\
\hline$\overline{\mathrm{N} \text { aundorff }}$ & hair & 62 & 14 & 4 & 32 & 12 \\
\hline N aundorff & bone & 13 & 0 & 0 & 11 & 2 \\
\hline $\begin{array}{l}\text { Johanna-G abriela } \\
\text { (J G ) }\end{array}$ & hair & 2 & 0 & 0 & 2 & 0 \\
\hline M aria-J osepha & hair & 2 & 0 & 0 & 2 & 0 \\
\hline $\begin{array}{l}\text { M arie-A ntoinette } \\
(\mathrm{M} \mathrm{A})\end{array}$ & $\begin{array}{l}\text { hair } \\
\text { Cannes }\end{array}$ & 5 & 1 & 0 & 2 & 2 \\
\hline $\begin{array}{l}\text { M arie-A ntoinette } \\
(\mathrm{MA})\end{array}$ & $\begin{array}{l}\text { hair } \\
\text { Nijmegen }\end{array}$ & 4 & 0 & 0 & 4 & 0 \\
\hline L ouise-M arie (L M ) & hair & 23 & 2 & 2 & 10 & 9 \\
\hline Charlotte $(\mathrm{CH})$ & hair & 36 & 1 & 3 & 26 & 6 \\
\hline
\end{tabular}

Incomplete sequences were due to premature 'stops', weak sequence signals, or to no obtained amplification product for some part of the D-loop.

compared with the Anderson sequence ${ }^{20}$ (Table 2). $N$ aundorff's hair and his bone (caput humerus) were independently analysed in $\mathrm{N}$ antes. The same techniques were used except that no nested PCR was performed to decrease the effect of contamination. Two different sources of $\mathrm{N}$ aundorff's hair were investigated: first from the grave (taken in 1950) and secondly from the corpse, taken after his death in 1845 . No results were obtained from the hair because of the low amount and/or degraded state of the DNA. A complete sequence was obtained from the bone which was identical to the common sequence found in Leuven (Table2). All sequences found in the hair from Naundorff were different from the sequences obtained from the humerus. Scanning electron microscopy (SE M) of some hair from Naundorff showed amorphous contaminating material around the hair shaft (Figure 3b) which was removed by a decontaminating differential lysis procedure prior to DNA extraction ${ }^{10}$ (Figure 3c). A fter decontamination, the hair shaft appeared fairly intact under SEM but no common sequence could be obtained. Pairwise analysis of the common sequence of the bone extracts with sequences obtained in two extensive studies of $m t D N A$ variation in European populations (G reat Britain, ${ }^{19}$ Belgium, P Deconte, 1997, unpublished results) revealed that the mtDNA sequence of $N$ aundorff was unique when the combined sequences for HVR 1 and HVR 2 were considered. In addition, the sequence was not found in a database of D -loop sequences from 233 U S Caucasians, $90 \mathrm{~A}$ frican Caucasians, 115 A fro-Caribbeans, 114 A fricans and $90 \mathrm{H}$ ispanics (M Holland, 1997, personal communication).

\section{Y-chromosomal DNA Analysis of the Remains of Naundorff}

In ten bone DNA samples, positive for mtDNA amplification, sex determination by co-amplification of the $X-Y$ homologous gene amelogenin was performed. ${ }^{16}$ Five DNA extracts were $X-Y$ positive, including four of the nine DNA extracts with an identical mtDNA sequence. The other extracts were without result and one extract was female, which confirmed contamination of this DNA extract. A dditional evidence for male sexing was obtained by analysing $\mathrm{Y}$-chromosomal short tandem repeats, mapping to the male-specific part of the human Y-chromosome, ${ }^{21}$ in bone D NA samples with an identical mtD NA sequence (data not shown).

\section{MtDNA Analysis of Hair Samples of Two} Aunts of Louis XVII

$H$ air samples from Johanna-G abriela (1750-1762) and M arie-Josepha (1751-1767), two aunts of Louis XVII (Figure 1), were used to establish the maternal mtD NA sequence of the family.

In the DNA extracts of four hair samples from the two aunts of Louis XVII (Table 1 ), three identical sequences were obtained. This sequence (found in two hairs from Johanna-Gabriela and in one hair from $M$ aria-Josepha) corresponded to the A nderson reference sequence ${ }^{20}$ for HVR 1 , whilst for HVR 2 two differences from the reference sequence were found (Table 2). A different sequence was found in one of the hairs from Maria-Josepha containing two nucleotide differences from the reference sequence from HVR 1 , whilst H V R 2 was identical to the three other sequences 
Table 2 Consensus sequence obtained for the different samples compared with the A nderson sequence 20

\begin{tabular}{|c|c|c|c|c|c|c|c|c|c|c|c|c|c|c|c|c|c|c|c|c|c|c|c|c|c|c|c|}
\hline \multirow[b]{2}{*}{ Origin of sample } & \multirow[b]{2}{*}{ Tissue sample } & \multicolumn{17}{|c|}{ HVR1 } & & \multicolumn{8}{|c|}{ HVR2 } \\
\hline & & 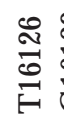 & & & & & & & & & & & & & & & & & & $\frac{m}{\pi}$ & & & & & & & \\
\hline \multirow{4}{*}{ Naundorff } & 8 samples caput humerus & * & & $*$ & * & * & $*$ & * & * & $*$ & $\mathrm{~T}$ & $*$ & $*$ & * & $*$ & * & $*$ & * & - & $*$ & * & * & $*$ & * & * & * G & G C \\
\hline & 1 sample caput humerus & * & $*$ & $*$ & $*$ & $\mathrm{Y}$ & $*$ & * & $*$ & $*$ & $\mathrm{Y}$ & $*$ & $*$ & * & * & * & $*$ & * & ND & $*$ & * & * & * & * & * & & $\mathrm{GCO}$ \\
\hline & 1 sample condylus humerus & * & & * & $*$ & * & $*$ & * & * & $*$ & $\mathrm{~T}$ & $*$ & * & * & $*$ & * & $*$ & * & - & $*$ & * & * & * & * & * & & $\mathrm{GC}$ \\
\hline & 1 sample condylus humerus & * & $*$ & * & $*$ & $\mathrm{Y}$ & * & * & * & $*$ & Y & $*$ & $*$ & * & $*$ & * & * & * & ND & $*$ & $*$ & * & * & * & * & * G & G C \\
\hline Naundorff (Nantes) & 2 samples caput humerus & * & $*$ & * & $*$ & $*$ & * & $*$ & * & $*$ & $\mathrm{~T}$ & $*$ & $*$ & * & * & * & $*$ & * & ND & $*$ & * & * & * & * & * & * G & $\mathrm{GCO}$ \\
\hline J ohanna-Gabriela (J G) & 2 hair samples & * & $*$ & * & * & * & * & * & * & $*$ & * & $*$ & * & * & $*$ & * & $*$ & * & + & $*$ & * & * & * & * & * & * G & $\mathrm{GC}$ \\
\hline \multirow[t]{2}{*}{ M aria-J osepha (MJ) } & 1 hair sample & $*$ & $*$ & $*$ & $*$ & $*$ & $*$ & $*$ & $*$ & $*$ & $*$ & $*$ & $*$ & $*$ & $*$ & * & $*$ & * & + & $*$ & $*$ & * & $*$ & * & $*$ & * G & $\mathrm{GC}$ \\
\hline & 1 hair sample & $*$ & $*$ & $*$ & $*$ & * & $*$ & * & $\mathrm{T}$ & $*$ & * & $*$ & $\mathrm{~T}$ & * & $*$ & * & $*$ & * & + & $*$ & * & * & $*$ & * & * & * G & $\mathrm{GC}$ \\
\hline \multirow{3}{*}{$\begin{array}{l}\text { Marie-A ntoinette (MA) } \\
\text { (Cannes) }\end{array}$} & 2 hair samples & $*$ & $*$ & $*$ & $*$ & $*$ & $*$ & $*$ & $*$ & $*$ & $*$ & $*$ & $*$ & $*$ & * & * & $*$ & * & + & $*$ & * & * & $*$ & * & * & * G & $G C$ \\
\hline & 1 hairs & $*$ & $*$ & $*$ & $*$ & $*$ & $*$ & * & $*$ & $*$ & $*$ & $*$ & $?$ & $?$ & ? & $?$ & $?$ & $?$ & + & $?$ & $?$ & $?$ & $?$ & ? & $?$ & $? \mathrm{G}$ & $\mathrm{GC}$ \\
\hline & 1 hair sample & $\mathrm{Y}$ & $\mathrm{R}$ & $\mathrm{R}$ & $\mathrm{Y}$ & * & $*$ & * & * & $*$ & $?$ & $?$ & $?$ & $?$ & ? & ? & $?$ & ? & + & G & * & * & * & & * & * G & $\mathrm{G} C$ \\
\hline \multirow{5}{*}{$\begin{array}{l}\text { Marie-A ntoinette } \\
\text { (MA) (Nijmegen) }\end{array}$} & 1 hair sample & $*$ & $*$ & $*$ & $*$ & * & $*$ & $*$ & $*$ & $*$ & * & $*$ & $*$ & $*$ & $*$ & * & $*$ & * & ND & $*$ & * & * & * & $*$ & $*$ & * G & G \\
\hline & 2 hair samples & $*$ & $*$ & $*$ & $*$ & $*$ & $*$ & $\mathrm{Y}$ & $*$ & $\mathrm{~T}$ & $*$ & $\mathrm{Y}$ & $*$ & $*$ & $*$ & $*$ & $\mathrm{Y}$ & $\mathrm{R}$ & ND & $\mathrm{R}$ & * & * & Y & * & * & Y G & GC \\
\hline & differential lysis buffer & $*$ & $*$ & $*$ & $*$ & $*$ & $*$ & C & $*$ & $\mathrm{~T}$ & $*$ & $\mathrm{~T}$ & $*$ & $*$ & $*$ & $*$ & C & $A$ & ND & G & * & * & C & * & $*$ & & $\mathrm{GC}$ \\
\hline & 1 hair sample & * & $*$ & $*$ & $*$ & * & $\mathrm{Y}$ & * & $*$ & $*$ & * & $\mathrm{T}$ & $*$ & $\mathrm{~T}$ & $Y$ & $\mathrm{R}$ & $\mathrm{Y}$ & * & ND & G & A & C & C & * & C & * G & $\mathrm{GC}$ \\
\hline & differential lysis buffer & $*$ & $*$ & $*$ & $*$ & $*$ & $\mathrm{~T}$ & $*$ & $*$ & $*$ & * & $\mathrm{T}$ & $*$ & $\mathrm{~T}$ & $\mathrm{~T}$ & G & C & * & ND & G & A & C & C & * & C & * G & $\mathrm{GCO}$ \\
\hline A nna (A) & blood sample & * & $*$ & $*$ & $*$ & * & $*$ & * & $*$ & $*$ & * & $*$ & $*$ & * & $*$ & * & * & * & + & $*$ & * & * & C & $\mathrm{T}$ & * & * G & $\mathrm{G} C$ \\
\hline A ndré (A B) (Nantes) & 1 hair sample & $*$ & $*$ & $*$ & $*$ & $*$ & $*$ & $*$ & $*$ & $*$ & $*$ & $*$ & $*$ & $*$ & * & $*$ & $*$ & * & ND & $*$ & * & $*$ & C & $\mathrm{T}$ & * & * G & $\mathrm{GC}$ \\
\hline
\end{tabular}

$\mathrm{Y}=\mathrm{C} / \mathrm{T}, \mathrm{R}=\mathrm{A} / \mathrm{G}, \mathrm{ND}=$ not determined, ? =sequence could not be determined.

HVR 1 is from approximately position 16030 to 16390; HVR 2 is from approximately position 60 to 400. 
a
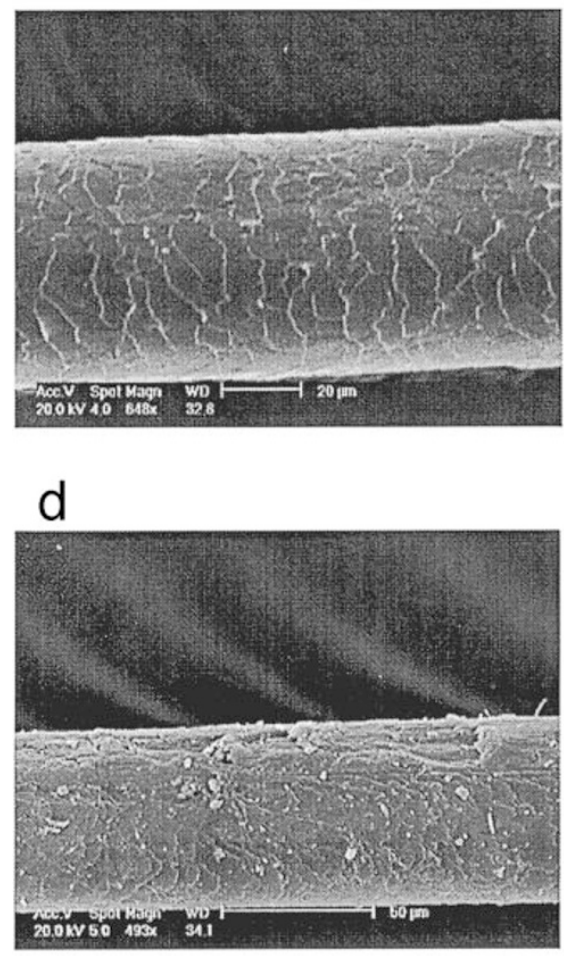

g

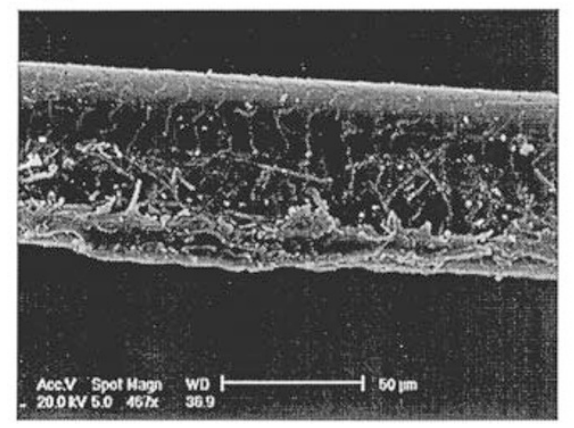

b

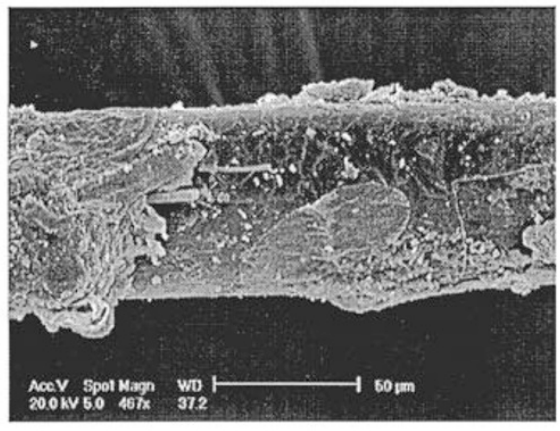

e

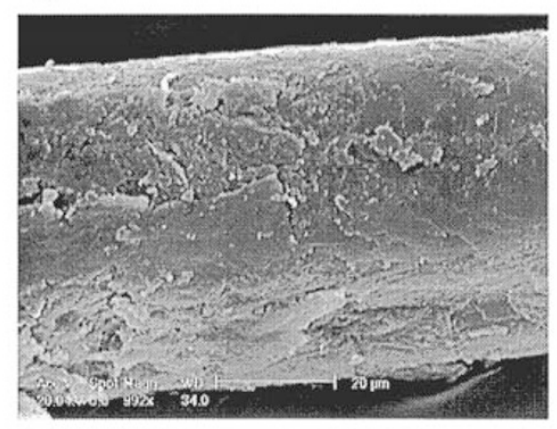

h

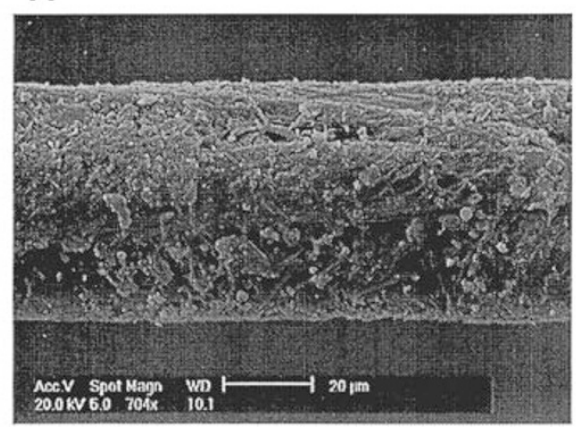

C

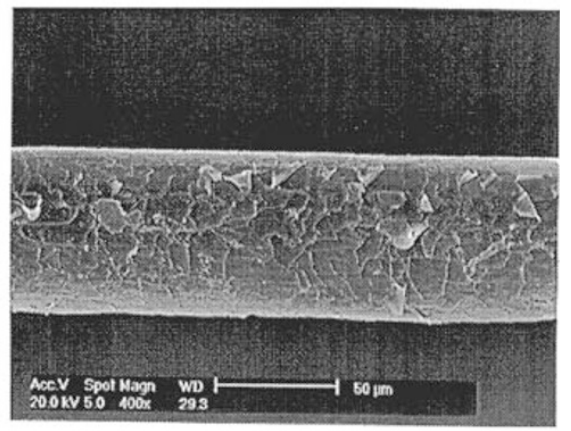

$\mathrm{f}$

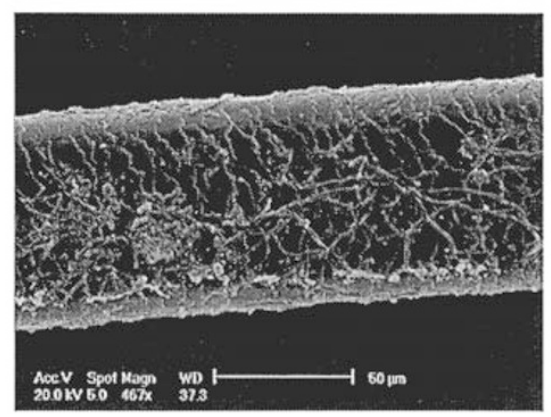

Figure 3 Scanning electron microscopy of hair samples of: a modern normal hair; $\mathbf{b}$ Naundorff's hair, prior to decontamination with a differential lysis buffer; $\mathbf{c} N$ aundorff's, after decontamination with a different lysis buffer; $\mathbf{d}$ L ouise-M arie; e Charlotte; $\mathbf{f}$ J ohannaG abriela; $\mathbf{g}$ M arie-A ntoinette (C annes); $\mathbf{h}$ M arie-A ntoinette ( $\mathrm{N}$ ijmegen).

two aunts of L ouis XVII with the sequence of the bone from Naundorff showed one difference in HVR 1, at nucleotide position 16260 . The sequence of the bone was also different from the other sequence found in one of the hairs from M aria-J osepha.

\section{Analysis of an Haelll Restriction Site Polymorphism at Position 16519}

A comparison of the $D$-loop sequences of the two aunts of Louis XVII with those of Naundorff, showed that there was only one nucleotide difference (Table2).
Since three meioses separate L ouis XVII from the two aunts, one nucleotide difference is insufficient to exclude $\mathrm{N}$ aundorff as a son of $\mathrm{M}$ arie-A ntoinette. It could be argued that $\mathrm{M}$ arie-A ntoinette was heteroplasmic at position $16260(\mathrm{C} / \mathrm{T})$ and that she transmitted a copy with the variant $16260 \mathrm{~T}$ to her son L ouis $X V I I$. Neither the DNA extracts of Naundorff, nor those of the two aunts of L ouis XVII, showed evidence of the presence of two nucleotides at position 16260 by direct sequence analysis of the PCR products. However, low levels of heteroplasmy can be missed by direct 
sequencing. Therefore $P C R$ products from the three hair DNA extracts from the two aunts of Louis XVII, showing identical mtD NA sequences, were cloned into pU C 18 vector with the SureC lone ligation kit (Pharmacia Biotech, Uppsala, Sweden), as described by the manufacturer. For each DNA extract ten positive colonies were isolated and sequenced. None of the 30 colonies showed a $T$ at position 16260. Therefore, no evidence of the presence of heteroplasmy could be found in the two sisters of $M$ arie-A ntoinette. Similarly, PCR products of a bone DNA extract of Naundorff, with the common sequence, were cloned and 16 positive colonies were analysed. Fourteen out of these showed a $T$ at position 16260 . The remaining two colonies with a $C$ at position 16260 could be the result of either a very low level of heteroplasmy, a contaminating sequence present in the bone extract, or Taq polymerase-mediated errors. Theoretically, a maximum of two mutations per colony would be expected for the cloned PCR product of $228 \mathrm{bp}$, after 45 cycles of amplification. ${ }^{22} \mathrm{O}$ ne of the two colonies showed this error rate because only one 'error' was present, compared with the common bone sequence of Naundorff. The other colony contained four 'errors' and, therefore, might be derived from a contaminating sequence, probably missed by direct sequencing. H owever, this cloning experiment could not be sufficiently conclusive to permit detection of very low levels of heteroplasmy in the bone sample of $\mathrm{N}$ aundorff.

In order to obtain additional genetic proof that would allow us to dismiss Naundorff as the son of $\mathrm{M}$ arie-A ntoinette, an $\mathrm{H}$ ael II restriction site polymorphism at position 16519 (wrongly identified as 16517 by B allinger et al. ${ }^{23}$ ) was analysed in the DNA of the bone sample from $\mathrm{N}$ aundorff and the hair of the two aunts of Louis XVII. It is known that the coding part of the $m t D N A$ is not very polymorphic, including the region between HVR 1 and HVR 2. Nevertheless the polymorphism at position 16519 is present in the population at high frequency. ${ }^{42-26} \mathrm{~A}$ study on 88 DNA samples of Belgian Caucasians revealed that the majority (68\%) had a T-to-C transition at position 16519 . The presence or the absence of the $\mathrm{H}$ ael II site at position 16519 was detected by enzymatic digestion and confirmed by sequencing of the obtained PCR products of the different DNA extracts. The DNA extracts of the two aunts of Louis XVII showed a gain of a $\mathrm{H}$ ael II restriction site at position 16519 as a result of a T-to-C transition, whereas the bone DNA sample from Naundorff showed no digestion at that position (Table2).
Therefore, the two nucleotide differences in the $D$-loop region (position 16260 and 16519) found between the consensus sequence of the humerus of $\mathrm{N}$ aundorff and those of the hair from two aunts of Louis XVII, strongly favour the hypothesis that Naundorff is not Louis XVII.

\section{MtDNA D-loop Analysis of Other Maternal Relatives of the Empress Maria-Theresia}

In order further to substantiate that the sequences obtained for the two aunts of Louis XVII were authentic, biological material from other descendants of the Empress M aria-Theresia, and, if possible, from living matrilineal descendants were sought. $\mathrm{H}$ air samples from L ouise Marie (1812-1850) and her daughter, Charlotte (1840-1927) (Figure 1) were obtained from envelopes kept in the archives of the R oyal Palace in B russels. Comparative samples from living maternal relatives of $M$ arie-A ntoinette were received from Q ueen A nna of R omania (blood sample) and from her brother André de Bourbon Parme (hair sample) (Figure 1). Finally, hair presumed to have been taken from $M$ arie-A ntoinette was made available from two sources. Firstly, hair was taken from two medallions kept in a private collection (Cannes) and secondly, from a document kept in the M useum 'C ommandery of Saint Jan' (Nijmegen).

Table 1 summarises the number of DNA extractions performed on the hair samples from $M$ arie-A ntoinette, L ouise-M arie and Charlotte. O nly mtD NA results of the hair samples from $M$ arie-A ntoinette were reproducible. Surprisingly, the two complete $\mathrm{mt} D$-loop sequences obtained from the hair of $\mathrm{M}$ arie-A ntoinette (Cannes) corresponded with the common sequences found in the hair of the two sisters (Table 2). O ne of the two incomplete $D$-loop sequences confirmed the other sequences. However, the other incomplete sequence showed four ambiguous positions which provided evidence for contamination of that particular hair D NA extract. A s in the hair of the two aunts of Louis XVII, a T-to-C transition at position 16519 was present in the hair DNA extracts of Marie-A ntoinette. PCR products of the two DNA extracts, showing an identical mtD NA sequence, were cloned in order to determine undetected heteroplasmy at position 16260 . Thirteen positive colonies were analysed. N one of them showed a $T$ at position 16260, excluding the possibility that M arieA ntoinette was heteroplasmic at this position. Two hairs from $M$ arie-A ntoinette were also analysed in $N$ antes but no results were obtained. In addition, hair samples from $M$ arie-A ntoinette from the second source 
(Nijmegen) were examined. The four DNA extracts showed in total three different sequences: three DNA extracts each contained two mixed sequences, whilst the fourth showed an unambiguous sequence identical to the sequence found in the previous hair samples from $M$ arie-A ntoinette. A nalysis of the differential lysis buffers, used to clean the hairs before their extraction, showed only one sequence. This sequence was present in the hair samples with a mixed sequence. Subtracting this contaminating sequence showed a sequence identical to those previous identified in the first source of hair samples from Marie-A ntoinette (Table 2). Therefore, these results provide additional evidence for the authenticity of the obtained common sequence of the two aunts of Louis XVII.

The 59 different extracts of the hair samples from Louise-M arie and Charlotte did not yield any common sequence. Contamination and/or the degraded state of DNA could be the cause of these findings. Moreover, scanning electron microscopy of the hair samples from L ouise-M arie and Charlotte revealed a very damaged hair shaft (Figures3d and Figure 3e). All sequences found in the hair from Louise-M arie and Charlotte were different from the sequences obtained from the humerus of $\mathrm{N}$ aundorff and from those of the two sisters of $M$ arie-A ntoinette.

Finally, DNA from two living maternal relatives of $M$ aria-Theresia were investigated. The D-loop sequence obtained from a blood sample from Q ueen A nna of R omania was independently confirmed by the sequence obtained from a hair sample from her brother, A ndré de Bourbon Parme, in Nantes. Both mtDNA D-loop sequences were identical and showed four polymorphisms compared to the Anderson sequence ${ }^{26}$ (Table 2). Pairwise analysis of the obtained sequence with sequences obtained from different $E$ uropean populations showed, as was the case for the sequence of $\mathrm{N}$ aundorff, a unique sequence. In addition, a $\mathrm{T}$ to $\mathrm{C}$ transition site at position 16519 was observed in the blood sample of Q ueen A nna. H owever, comparison of the common mtDNA D-loop sequence of the three sisters, Johanna-G abriela, M aria-Josepha and $M$ arie-A ntoinette with the sequence obtained from the living maternal relatives showed two differences in H V R 2. Several explanations for this mismatch between the maternal relatives of the $\mathrm{E}$ mpress $\mathrm{M}$ aria-Theresia can be formulated, such as: 1 ) the family shows a very high mutation rate, 2) the hair from the daughters of $M$ aria-Theresia or the obtained sequences are not authentic, or 3) Q ueen A nna and her brother are the descendants of a female adopted several generations earlier.

Nevertheless, the mtD NA sequence obtained for the two living maternal relatives makes it even more unlikely that Naundorff could be Louis XVII.

\section{Discussion}

The present study provides evidence for the fact that the remains of $N$ aundorff cannot be identified as those of Louis XVII, son of Louis XVI and Marie-A ntoinette. This tentative conclusion is supported by the comparative mtDNA analysis of bone sample from $N$ aundorff and of DNA samples from two living maternal relatives of Louis XVII, as well as by DNA analysis of hair samples from maternal relatives of L ouis XVII, including two of his aunts and of M arieA ntoinette herself. Whilst the differences in mtD NA sequences between the daughters of $M$ aria-Theresia and A nna of Romania and her brother A ndré are puzzling, the two sets of data point towards a difference in the mtDNA sequence of Naundorff and a son of $M$ arie-A ntoinette. Hair samples from two further maternal relatives, Louise-M arie, Q ueen of Belgium, and her daughter Charlotte, did not however allow us to find an authentic mtD NA sequence due to the poor condition of the hair shafts of these samples. This was also true of the hair samples from Naundorff, which were used in a first approach to establish the mtD NA sequence of Naundorff. The use of a decontaminating differential lysis procedure prior to DNA extraction, which has proven to be efficient in removing contaminated saliva or blood from modern hair, ${ }^{10}$ should have removed the contaminating DNA. However, application of this method or any alternative method ${ }^{27}$ on hairs with damaged hair shaft is apparently not efficient in removing contaminating material completely. The differential lysis buffer might also have penetrated the hair shaft resulting in a substantial loss of hair DNA. Moreover, the contaminating DNA could also have entered the damaged hair shaft. Surprisingly, much older hairs from Johanna-G abriela, M aria-J osepha and $M$ aria-A ntoinette showed better preservation of the shaft (SE M, (Figures $3 f$ and $3 g$ ) and also revealed a common sequence. The hair from the two aunts of L ouis XVII and his mother (first source) had been kept in a medallion for more than 200 years. The present study demonstrates that whilst mtDNA analysis on ancient hair samples is feasible, great variability exists in the quality of the hair. In many families, it is still 
customary to preserve hair from family members of previous generations. This material will in many cases be usable for establishing (or excluding) maternal relationships. O ne requisite is that the hair shaft should be intact, which can be determined by scanning by electron microscopy.

Comparison of the mtDNA sequence of the bone from Naundorff and of the two aunts of Louis XVII showed two differences. One is located in HVR 1 (16260) and the other in the region between H VR 1 and H V R 2 (16519). Studies on native A mericans, ${ }^{28,29}$ A fricans $^{30}$ and E uropeans ${ }^{31}$ have demonstrated that nucleotide position 16519 is hypervariable and mutates faster on average than the other sites in the non-coding region. The use of the $16519 \mathrm{H}$ ael II polymorphism is, therefore, questionable in phylogenetic studies. This does not imply, however, that it cannot be used for determining maternal relationships. In the case of Naundorff, it provides substantial evidence for his exclusion as the son of $\mathrm{M}$ arie-A ntoinette. In contrast to all the investigated DNA samples of the maternal relatives of L ouis XVII, only the bone from Naundorff showed no mutation at position 16519. At position 16260 no evidence of heteroplasmy was found in the three daughters of Maria-Theresia. No evidence for heteroplasmy was found in any of the cloned mtD NA sequences of different hairs from the three different persons which were sampled at different times.

Two nucleotide differences were found between the $m t D N A$ sequence of the living maternal relatives of L ouis XVII and the two aunts and the mother of L ouis $X V I I$. Three possible hypotheses can be proposed to explain this discrepancy. A first hypothesis could be that the hair samples of the three sisters are not authentic. In contrast to the hair samples from M aria-Josepha, Johanna-Gabriela and Naundorff (see methodology), the origin of the hair samples of $\mathrm{M}$ arie-A ntoinette could be questioned. Concerning the first source of hair from Marie-A ntoinette, only oral information transmitted in the families who possessed the two medallions was available. $\mathrm{H}$ owever, the second source of hair was authenticated in the head of $\mathrm{Henri}$ Prince de B ourbon and the official stamp of the B ourbon was on the document. Whilst final proof of the authenticity of the hair sample from Marie-A ntoinette is lacking, the same mtDNA D-loop sequence as in the sisters was found. Moreover, these samples were kept under different conditions, glued in medallions in the case of J ohanna-G abriela and $M$ aria-J osepha, dried in a medallion in the case of the first sample from Marie-
A ntoinette and air dried on cardboard in the second. It is therefore very unlikely that the three hair samples belonged to three unrelated individuals and that only a common contaminating sequence, different from that of our laboratory personnel was found. The chance of finding the same sequence (that of $M$ arie-A ntoinette) in two unrelated persons, if we accept that $M$ ariaJosepha and Johanna-Gabriela were sisters, is $1.7 \times$ $10^{-3}$ with a haplotype frequency of 9 in 219 Caucasians ( $100 \mathrm{~B}$ ritish and $119 \mathrm{~B}$ elgian individuals). The chance of these three persons being unrelated is even more unlikely $\left(P=6.9 \times 10^{-5}\right)$. By using a Bayesian approach (see methodology section), a likelihood ratio of 215 (to 1 significant figure) was obtained, which means that it is 215 times more likely that the hair is from a maternal relative of Maria-Josepha and Johanna-Gabriela, than not. This LR represents an upper bound since it was based on the probability of finding at random two individuals with an identical sequence. A lower bound for the LR would be 25:1 when the frequency of the mtD NA sequence (0.037) of $\mathrm{M}$ aria-A ntoinette in the population (7 in $100 \mathrm{British}$ and 3 in 168 B elgians) is used. The second hypothesis is most unlikely, namely that a female child in the pedigree of E mpress $M$ aria-Theresia was adopted, and introduced another mtDNA sequence into the family which was then transmitted to Queen A nna and her brother. Evidence for this hypothesis would probably be available in official or historical records. A third hypothesis might be that during nine meioses, which separate the three sisters from Q ueen A nna and her brother, two mutations occurred. Parsons et al. ${ }^{18}$ calculated the intergenerational substitution rate, resulting in an average rate of 1 in 33 generations. The data also indicated that extremely rapid segregation of control region sequence variants between generations is common in humans and, therefore, that a very small mtD NA bottleneck is present. However, the substitution rate calculated by Parsons et al. ${ }^{18}$ is seven times lower than the empirical rate of 2 in 9 or 1 in 4.5 generations observed in our study. It might also be, as Parsons et al. ${ }^{18}$ also observed, that some families accumulate mutations faster than others and that the family of the Empress Maria-Theresia is such an example. Moreover, the two mutations observed in the living maternal relatives of Louis XVII are present in HVR 2, which is known to have a higher heterogeneity rate than HVR $1 .{ }^{32}$ One of the two HVR 2 positions, position 152 , is among the fastest-evolving positions in the $\mathrm{D}$-loop, as determined by phylogenetic analysis. ${ }^{31}$ 
The other position (194) is next to another fast-evolving position, namely 195 . In order to prove that two mutations appeared during the nine meioses which separate the living maternal relatives from the others, it would be necessary to analyse remains of other maternal family members. Our attempt to use hair samples from Queen Louise-M arie and her daughter Charlotte failed, however, due to the poor preservation of the hair shafts.

The tentative exclusion of N aundorff as Louis X V II in the present study finds support in an independent historical investigation. ${ }^{33} \mathrm{H}$ owever, it will undoubtedly be contested by the large numbers of authors and experts who came to the opposite conclusion. There are no official records that prove the claim of Naundorff that he was the son of Louis XVI and MarieA ntoinette. A nalysis of the physical features of Naundorff and Louis XVII, of the color and structure of the hair, and the location of physical injuries were either inconclusive or favoured differences (reviewed by Petrie ${ }^{33}$ ).

In this regard a DNA analysis on the remains of the boy who died in the Temple on 8 June 1795 would be important. He was presumably buried in a mass grave at the cemetery of Sainte-M arguerite (Paris), but his remains were never found. A fter his death, an autopsy was done by four physicians. O ne of these (Pelletan) apparently put the heart of the boy in his pocket. This heart was donated to the royal crypt of the Basilique Saint-D enis (Paris) where it is still kept. If the origin and the authenticity of this heart can be proven, D NA analysis on these remains might show that the boy who died in the Temple on 8 J une 1795 is or is not the child of $M$ arie-A ntoinette and, if confirmed, put an end to the theory of a substitute. A uthorisation for such a study could not be obtained.

Independent study of other remains of $\mathrm{N}$ aundorff and of other descendants of Maria-Theresia, if confirmatory, should allow this fascinating problem, to be resolved.

\section{Acknowledgements}

We are in debt to a large number of persons who contributed to the successful completion of these investigations: Prince Charles L ouis de B ourbon and Prince Charles L ouis E dmond de Bourbon, descendants of Naundorff, for their continued interest in our search for objective evidence: DSK Schoor, counsel of Prince Charles de Bourbon (A msterdam); $E$ Persoons, director general of the National A rchives (Brussels); J R oegiers, D epartment of $\mathrm{H}$ istory (L euven); $M$ arquis de Trazegnies (B russels); F Pichornes (Wien); Sister M ichael;
Elisabethinen convent (Klagenfurt); C Topper, A rchivdirektorin der D iözese G urk (K lagenfurt); G K apsch, goldsmith (K lagenfurt); AV van Walsum, former mayor of the city of Delft; A HJ Rozemund, archivist of the city of Delft; A D K loosterman, Forensic Science Laboratory (R ijswijk); W Froentjes, retired scientist (D en Haag); F U ddenberg, conservator, Forensic Science L aboratory (R ijswijk); M arquise Jane de Bernardières (Cannes); J Van Y persele de Strihou, chef de cabinet to the $K$ ing of B elgium (B russels); $G$ Janssens, archivist at the Royal Palace (Brussels); JA Ph Laguette, member of the committee of Graeft Voort Foundation (G rave); $G \mathrm{~L}$ emmens, director of the museum (Commandery of Saint Jan Nijmegen); GGAM Pijnenborg, sometime librarian of the $U$ niversity of Nijmegen; and Q ueen A nna of R omania and A de Bourbon Parme for contributing comparative biological samples.

The technical support of B Van D er Schueren for the SE M analyses of the hair is gratefully acknowledged; we are also grateful to $\mathrm{M} \mathrm{H}$ olland (A rmy Forces Institute of Pathology, Washington) for providing us data from the mtD NA database of the US A rmy Forces.

\section{References}

$1 \mathrm{H}$ agelberg E, Gray IC, Jeffreys A J : Identification of the skeletal remains of a murder victim by DNA analysis. Nature 1991; 352: 427-429.

2 G ill P, Ivanov PL, K impton $C$ et al: Identification of the remains of the Romanov family by DNA analysis. $N$ at G enet 1994; 6: 130-135.

3 Jeffreys A J, A llen MJ, H agelberg E, Sonnberg A : I dentification of the skeletal remains of J osef $M$ engele by $D N A$ analysis. Forensic Science Int 1992; 56: 65-76.

4 A quadro CF, G reenberg BD: H uman mitochondrial DNA variation and evolution: analysis of nucleotide sequences from seven individuals. G enetics 1983; 103: 287-312.

5 Orrego $C, K$ ing $M C$ : D etermination of familial relationships. In: Innis MA, G elfand DH, Sninsky JJ, White T] (eds). PCR Protocols. A cademic Press: London: 1990; pp 416-426.

6 Bogenhagen D, Clayton DA : The number of mitochondrial deoxyribonucleic acid genomes in mouse $\mathrm{L}$ and human HeLa cells. J Biol Chem 1974; 249: 7991-7995.

7 R ogan PK, Salvo J]: M olecular genetics of pre-Columbian South A merican mummies. Yearbook of Physical A nthropology 1990; 33: 195-214.

$8 \mathrm{H}$ agel berg $\mathrm{E}$, Sykes $\mathrm{B}, \mathrm{H}$ edges $\mathrm{R}$ : A ncient bone amplified. Nature 1989; 342: 485.

$9 \mathrm{~K}$ rings $\mathrm{M}$, Stone $A$, Schmitz RW, Krainitzki H, Stoneking $M$, Pääbo S: N eanderthal DNA sequences and the origin of modern humans. Cell 1997; 90: 19-30.

10 Jehaes E, G ilissen A, D ecorte R, Cassiman J -J : E valuation of a decontamination protocol for hair shafts before mtD NA sequencing. Forensic Science Int. 1998.

$11 \mathrm{H}$ iguchi $\mathrm{R}$, von Beroldingen $\mathrm{CH}$, Sensabaugh $\mathrm{G}$, Erlich HA: DNA typing from single hairs. Nature 1988; 332: 543-546.

12 Höss M , Pääbo S: D NA extraction from pleistocene bones by a silica-based purification method. Nucleic A cids R es 1993; 21: 3913-3914. 
13 Decorte R, Jehaes E, Xiao, FX, Cassiman J-J: G enetic analysis of single hair shafts by automated sequence analysis of the mitochondrial $D$-loop region. Adv For H aemogen 1996; 6: 17-20.

14 Jehaes E, Habex H, Decorte R, Charlier C, Van Den B erghe $\mathrm{H}$, Cassiman I $\mathrm{J}$ : I solation and characterization of mitochondrial DNA from ancient remains; application to bone samples from the archaeological site at ErpsKwerps. Acta Archaeologica Lovaniensia 1994; 33: 101-106.

15 Sanger F, Nicklen S, Coulson A R : D NA sequencing with chain-terminating inhibitors. Proc Natl Acad Sci USA 1977; 74: 5463-5467.

16 Sullivan K M , M annuci A , K impton CP, G ill P: A rapid and quantitative DNA sex test: Fluorescence-based $P C R$ analysis of $X-Y$ homologous gene amelogenin. Biotechniques 1993; 15: 100-119.

17 Decorte R, Cassiman J-J : Evaluation of the A LF DNA sequencer for high-speed sizing of short tandem repeat alleles. Electrophoresis 1996; 15: 1542-1549.

18 Parsons TJ, M uniec DS, Sullivan $K$ et al: A high observed substitution rate in the human mitochondrial DNA control region. Nat G enet 1997; 15: 363-368.

19 Piercy R, Sullivan K M , Benson N, G ill P: The application of mitochondrial DNA typing to the study of white Caucasian identification. Int J Legal Med 1993; 106: 85-90.

20 A nderson S, Bankier AT, B arrel BG et al: Sequence and organization of the human mitochondrial genome. $\mathrm{N}$ ature 1981; 290: 457-465.

21 Kayser M, Caglia A, Corach D et al: Evolution of Y-chromosomal STR s: a multicenter study. Int J L egal M ed 1997; 110: 125-133.

22 E ckert KA, K unkel TA : D NA polymerase fidelity and the polymerase chain reaction. PCR M ethods Appl 1991; 1: 17-24.

23 Ballinger SW, Schurr T G, Torroni A et al: Southeast A sian mitochondrial DNA analysis reveals genetic continuity of ancient Monogoloid migrations. Genetics 1992; 130: 139-152.
24 Greenberg BD, Newbold JE, Sugino A: Intraspecific nucleotide sequence variability surrounding the origin of replication in human mitochondrial DNA. G ene 1983; 21: 33-49.

$25 \mathrm{H}$ orai S, Hayasaka $\mathrm{K}$ : Intraspecific nucleotide sequence differences in the major noncoding region of human mitochondrial DNA. Am J Hum G enet 1990; 46: 828-842.

26 Horai S, Kondo R, Nakagawa-Hattori $\mathrm{Y}, \mathrm{H}$ ayashi $\mathrm{S}$, Sonoda S, Tajima K : Peopling of the A mericas, founded by four major lineages of mitochondrial D NA. M ol Biol E vol 1993; 10: 23-47.

27 Wilson M R, Polanskey D, Butler J, DiZinno JA, R eplogle J, B udowle B: Extraction, PCR amplification and sequencing of mitochondrial DNA from human hair shafts. B iotechniques 1995; 18: 662-669.

28 Torroni A, Sukernik RI, Schurr TG et al: A sian affinities and continental radiation of the four founding $\mathrm{N}$ ative A merican mtDNAs. Am J Hum Genet 1993; 53: 563-559.

29 Torroni A, Sukernik RI, Schurr TG et al: mtDNA variation of aboriginal Siberians reveals distinct genetic affinities with Native A mericans. A m J H um G enet 1993; 53: 591-608.

30 Chen Y S, Torroni A, Excoffier L, Santachiara-B enerecetti $A S$, Wallace D C: A nalysis of $m t D N A$ variation in A frican populations reveals the most ancient of all human continent-specific haplogroups. A m J H um G enet 1995; 57: 133-149.

31 Torroni A, H uopen K, Francalacci P et al: Classification of E uropean mtD NA s from an analysis of three European populations. G enetics 1996; 144: 1835-1850.

32 A ris-Brosou S, Excoffier L: The impact of population expansion and mutation rate heterogeneity on DNA sequence polymorphism. Mol Biol Evol 1996; 13: 494-504.

33 Petrie J H : L odewijk XVII-N aundorff, een mysterie ontrafeld. De B ataafsche L eeuw: A msterdam, 1995. 